\title{
Experience Of The Justice Bodies In Foreign Countries In The Field Of Law-Making: A Comparative Legal Analysis
}

\author{
Kudryavtsev Igor Vladimirovich \\ Professor, Department of Theory of the state and law of Tashkent State University of Law. Tashkent city, Uzbekistan. Email: \\ i.kudryavtsev@tsul.uz
}

\section{Khujanazarov Azizjon Anvarovich}

Teacher, Department of Theory of the state and law of Tashkent State University of Law. Tashkent city, Uzbekistan. Email: a.xujanazarov@tsul.uz

\begin{abstract}
Objective: To analyze the experience of the justice bodies in foreign countries in the field of law-making. Methods: A comparative legal analysis study was conducted. It involved 10 justice bodies in foreign countries between Asia and other foreign countries in the field of law-making. Results: The results report the significant effectiveness of the law-making activities of the justice bodies in foreign countries and implementation of the experience about law-making in the activities of the justice bodies of the Republic of Uzbekistan. Conclusions: The study and comparison of the experience of the justice bodies of foreign countries in the field of law-making give suggestions for improving national legislation.
\end{abstract}

Keywords:

law, legal, norm, justice, state, industry, legislation.

Article Received: 18 October 2020, Revised: 3 November 2020, Accepted: 24 December 2020

\section{INTRODUCTION}

In recent years, modern management methods have been applied to the activities of lawmaker bodies around the world, and innovative technologies have been widely introduced into the industry. This trend is one of the effective criteria for the preparation of draft legislation in foreign countries, further increase the efficiency of their legal examination and the adoption of quality legislation.

In particular, the rule of law is a priority (The WJP Rule of Law Index) is one of the main evaluation requirements, and the project publishes a ranking of 128 countries each year.

Several scientific types of research are carried out in the world to further improve the law-making activity of state bodies, in particular, the development of justice activity in this area, including theoretical and methodological analysis of norm-setting activity, organizational-legal bases of norm-making activity of justice bodies. Special attention is paid to the introduction of technologies, as well as the application of elements of the model of "smart regulation" in this area as a research area of great scientific and practical importance.

Further development of the role of the judiciary in the law-making activity, the formation of consistent and uniform law enforcement practices, ensuring the effectiveness of public administration, improving the legal culture of the population, further development of the judiciary and institutions.

In foreign countries, the activities of the judiciary in the field of law-making are organized in different directions. Based on the goals and directions of our research, it is expedient to systematically analyze the activities of some foreign justice bodies in this area.

\section{METHODS}

A comparative legal analysis study was conducted. It involved 10 justice bodies in foreign 
countries between Asia and other foreign countries in the field of law-making.

The phenomenon of state and law through the method of comparison and views (opinions) are studied by comparison.

The comparative-legal method is important in the methodology of state and law, along with the exact-sociological method. The comparative method involves comparing concepts, events, and processes and identifying similarities and differences between them. The comparison determines the qualitative state of the legal system as a whole, state-building, or, for example, legal institutions and norms taken separately.

However, an important condition must be taken into account here - that is, the objects to be compared must be truly comparable. We will explain in examples. It is possible to compare legal systems, state structures, legal institutions and rules of the same name. But, for example, an entire legal system cannot be compared to some derived legal rule. These objects cannot be compared in terms of their level, size, content and characteristics.

Let's say that if you compare high-level objects (legal systems of different countries) that are complex in their composition - this is a macro comparison. It is called microcomparison if we compare objects of small size, composition, etc. (legal rules, the level of crime in the regions of the republic).

At the same time, it is impossible to reform or improve the practice of state-politics and law without comparing similar objects of knowledge that existed in different periods of the past. State or legal systems of different historical types, in different countries and continents, in the same country can be compared. However, if they belong to different stages of socio-economic development - such comparisons do not make any sense. The only thing that is important is to analyze the quantitative and qualitative aspects of the object, its theoretical and practical description in order to find the truth.

The method of comparison is very important in jurisprudence, jurisprudence and legal practice. In particular, it became clear to science that the basis and result of the comparison was that each subsequent stage of the development of the state and law was more advanced than the previous one.

Only by comparing legal materials and obtaining results can concrete ways to improve the legal system, improve the work of the legislature, and strengthen the rule of law and order be identified.

\section{RESULTS}

The Ministry of Justice of the Russian Federation, in accordance with subparagraph 8) of paragraph 7 of the Regulation "On the Ministry of Justice of the Russian Federation", approved by Presidential Decree No. 1313 of 13 October 2004, subdivisions of services submit to the President and the Government of the Russian Federation drafts of federal constitutional laws, draft federal laws, documents of the President and the Government of the Russian Federation and other documents in accordance with the activities of the draft work plans and forecast indicators. According to the charter, the ministry is involved in the preparation of official reviews and conclusions of federal constitutional laws and draft federal laws, as well as in drafting amendments to them.

Item 6 of the Regulation "About managements of the Ministry of Justice of the Russian Federation on subjects of the Russian Federation", approved by the order of the Minister of Justice of the Russian Federation from March 3, 2014 of No. 26 3) in accordance with subparagraph, the departments of the Ministry on the subjects of the Federation in the prescribed manner develop proposals on amendments to federal constitutional laws, federal laws, acts of the President and Government of the Russian Federation and other documents, as well as draft laws, acts and documents. Submits to the Ministry of Justice. 
In accordance with this Regulation, the Department of Justice submits to the Ministry of Justice proposals on amendments to the normative legal acts of the Ministry of Justice of Russia and the adoption of such normative legal acts in the prescribed manner.

According to subparagraph 6.1 of the Regulation "On the Ministry of Justice of the Republic of Belarus", approved by the Council of Ministers of the Republic of Belarus on 31.10.2001 No 1605, the Ministry of Justice on behalf of the President of the Republic of Belarus develops draft documents.

According to Article 15 of the Law of the Republic of Kazakhstan "On Justice Bodies" of March 18, 2002, the judiciary carries out the work of draft laws and draft regulations.

Department IV (Constitutional and Administrative Law, International and European Law) within the structure of the German Federal Ministry of Justice and Consumer Protection is involved in the development and negotiation of international legal treaties. Also, this Department IV is responsible for the preparation and implementation of the agreements established under the auspices of the UN and the Council of Europe

The Ministry of Justice of France has a number of norm-setting structures, including the Office for Civil Affairs, which draft laws and regulations related to constitutional law, administrative matters, civil law and civil procedure, corporate law and commercial law

One of the main responsibilities of an employee of the Ministry of Justice of Finland is to develop Government bills

\section{DISCUSSION}

The Ministry of Justice of the Russian Federation, in accordance with the Regulation "On the Ministry of Justice of the Russian Federation", the Ministry of Justice of the Russian Federation conducts the legal examination of draft terms of reference. According to this Regulation, the Ministry of Justice of the Russian Federation will accredit experts to conduct an independent anticorruption examination of normative legal acts and their drafts [8].

Subparagraph 12) of paragraph 6 of the Regulations on the Departments of the Ministry of Justice of the Russian Federation provides for the legal examination of normative legal acts of the subjects of the Russian Federation on the subject of compliance with the Constitution and laws of the Federation. A copy of the expert opinion on the contradiction of the normative legal acts of the subjects of the Russian Federation with the Constitution and (or) the laws of the Federation shall be submitted to the prosecutor's office for the application of the prosecutor's sanction.

In our opinion, it is expedient to introduce the above-mentioned experience of the justice bodies of the Russian Federation in the field of law-making into the legislation of our country.

According to subparagraph 5.3 of the Regulation "On the Ministry of Justice of the Republic of Belarus", approved by the Council of Ministers of the Republic of Belarus on 31.10.2001 No 1605, the Ministry of Justice, the National Bank, the State Control Committee, the Office of the President, the Investigative Committee Mandatory legal examination of normative legal acts of the Committee, the National Academy of Sciences of Belarus, ministries, other state bodies of the republic, the Councils of People's Deputies of the regions and the city of Minsk, regional executive committees and executive committees of the city of Minsk. Sub-clause 6.4 of the Regulation stipulates that the Ministry of Justice of Belarus conducts mandatory legal examination and conclusion of draft resolutions of the Council of Ministers of the Republic, as well as draws conclusions on draft international agreements and investment agreements, provides legal opinions on loan agreements guaranteed by the Government. draft agreements, decrees, decrees and orders.

In the Republic of Kazakhstan, the justice bodies carry out legal examination of normative legal acts and loan agreements guaranteed by 
Kazakhstan. At the same time, normative legal acts of central state bodies, agencies, akimat (khokimiyat) and akim (khokim) are registered in the justice bodies of this country.

Department IV of the German Federal Ministry of Justice and Consumer Protection conducts the legal examination of draft laws and decisions in terms of compliance with the rules of norm-making. As part of the legal expertise, the Department examines draft laws and decisions of other federal ministries for compliance with applicable law. It also takes into account the classification of legislation and adherence to the principles of legal logic. Department IV is also responsible for drawing up legal conclusions on projects in the field of international law with the participation of the Federal Republic of Germany, including human rights.

In addition, another structure of the Ministry of Justice of the Federal Republic of Germany, Department III (Trade and Economic Law), also provides legal opinions on draft laws and resolutions developed by the Ministries of Taxation, Finance and Economic Law.

In accordance with the Canadian Law on the Ministry of Justice, the Ministry will conduct a legal examination of the provisions of the bill for compliance with the provisions of the Canadian Charter of Freedom and Rights.

Singapore's Ministry of Justice examines all types of government-related bills for compliance with the Singapore Constitution and sound legal policy principles.

The Department of Civil Rights of the Ministry of Justice of the Republic of Poland monitors and analyzes areas of work on draft government laws, draft EU legislation, draft international agreements.

The Ministry of Justice of the Russian Federation coordinates the work of the federal executive bodies on the preparation of proposals for the draft law on the activities of the Government and, if necessary, provides a legal opinion on the expediency of drafting laws. The ministry also generalizes the practice of preparing federal constitutional laws and draft federal laws by federal ministries and provides methodological support for their preparation.

According to subparagraph 5.2 of the Regulation "On the Ministry of Justice of the Republic of Belarus", approved by the Council of Ministers of the Republic of Belarus on 31.10.2001 No 1605, the Ministry provides coordination of law-making activities in the Government. The Ministry of Justice of Belarus is represented by the National Bank, the State Control Committee, the Office of the President of the Republic of Belarus, the Investigative Committee, the State Committee for Forensic Science, the National Academy of Sciences of Belarus, regional and Minsk city councils, regional executive committees and ministries. study of the state of normative activity in the state bodies of the republic and introduction of obligatory submissions to these state bodies on the elimination of violations of the normative state revealed by the results of the inspection, in case of non-fulfilment of this proposal, a proposal will be submitted to the Council of Ministers to bring to disciplinary responsibility the officials of the ministries and other public administration bodies of the Republic.

The Ministry of Justice of the Republic of Moldova provides explanations and recommendations to government agencies related to the technique of drafting regulations.

It should be noted that it is expedient to adopt the Law on Justice in our country on the basis of the experience of the Republic of Kazakhstan among the countries of Canada and the CIS, which have unified the legislation governing the field of justice.

In addition, the legal description of the concepts related to the field can be analyzed on the example of the norms in the normative legal acts of the following foreign countries.

In particular, Article 2 of the Law of the Republic of Belarus "On regulatory legal acts" of July 17, 2018 states "legislative initiative", "lawmaking initiative", "law-making activity", "norm- 
making activity", "norm-making technique", The concept of "subjects of norm-setting" is noteworthy, and these concepts are defined by law as follows:

- Legislative initiative - is the official submission of a bill to the House of Representatives of the National Assembly of the Republic by entities that have the right of legislative initiative in the manner prescribed by the Constitution of the Republic of Belarus;

- norm-setting initiative - is the period of adoption (issuance), amendment, official interpretation, termination, renewal, validity of normative-legal document (elements of its structure) to the norm-setting body (official) by the subjects having norm-creation initiative. formal submission of a draft normative legal act or substantiated proposals on the need for extension and termination;

- Legislative activity - is the activity of the state power to implement the right of legislative initiative, planning, preparation of laws, legal examination, adoption, official interpretation, amendment, official publication, termination, renewal, extension and termination of laws;

- norm-setting activity - is the implementation, planning, preparation of laws, legal examination, adoption (issuance), official interpretation, amendment, official publication, termination, renewal, extension and termination of normative-legal acts. activities of the state power;

- Norm-creating technique - is a system of rules for the preparation of draft regulations;

- subjects of norm-setting - these are state bodies, other organizations (officials), citizens of the Republic of Belarus, as well as foreign citizens or stateless persons temporarily residing, temporarily or permanently residing in the Republic of Belarus, individual entrepreneurs.

Article 1 of the Constitutional Law of the Republic of Azerbaijan dated December 21, 2010 "On normative legal acts" stipulates that normative activity is the preparation, examination, acceptance, amendment, interpretation, termination or revocation of draft normative legal acts.

\section{CONCLUSION}

The study and comparison of the experience of the justice bodies of foreign countries in the field of law-making gives suggestions for improving national legislation.

Based on the law-making activities of the justice bodies of foreign countries, the following proposals can be made:

First, the introduction of digital technologies by the justice bodies in the implementation of law-making activities, such as elements of "smart regulation".

Second, to inform the competent authorities about serious violations and other violations identified during the legal examination of draft regulations.

Third, it is important to further improve the monitoring of the law-making activities of government agencies by the justice bodies.

\section{ACKNOWLEDGMENTS}

We would like to express our deep gratitude to Prof. M. Najimov for his valuable assistance to conduct the research. Furthermore, we also thank the other professors of the Department of Theory of the state and law of TSUL for providing scientific material.

\section{REFERENCES}

[1] https://worldjusticeproject.org/ourwork/wjp-rule-law-index/wjp-rule-lawindex-2017\%E2\%80\%932018/factorsrule-law/regulatory-enforcement

[2] https://minjust.ru/ru/print/43436

[3] http://www.pravo.by/document/?guid=387 $1 \& \mathrm{p} 0=\mathrm{C} 20101605$

[4] http:///online.zakon.kz

[5] www.bmjv.de

[6] https://www.legifrance.gouv.fr/affichTexte .do?cidTexte=JORFTEXT000019153062 $\&$ dateTexte $=20200601$

[7] https://finlex.fi/fi/laki/ajantasa/2019/20190 595\#L3P8 
[8] https://laws-lois.justice.gc.ca/eng/acts/J2/page-1.html\#s-4

[9] https://www.mlaw.gov.sg/about-us/whatwe-do/legal-group/

[10] https://www.gov.pl/web/sprawiedliwosc/d epartament-legislacyjny-prawa-cywilnego

[11] https://www.legis.md/cautare/getResults?d oc_id $=93122 \&$ lang $=r u$

[12] National legal Internet portal of the Republic of Belarus, 31.07.2018, 2/2568.

[13] https://www.legislationline.org/download/i d/8109/file/Azerbaijan_law_normative_act s_2010_ru.pdf. 